\title{
Application of an Intramolecular Stetter Reaction to Access trans,syn,trans- Fused Pyrans
}

\author{
Christopher S. P. McErlean, ${ }^{* a}$ Anthony C. Willis ${ }^{\mathrm{b}}$ \\ a School of Chemistry, The University of Sydney, Sydney, NSW 2006, Australia \\ Fax +61(2)93513329; E-mail: C.McErlean@chem.usyd.edu.au \\ b Research School of Chemistry, The Australian National University, Canberra, ACT 0200, Australia \\ Received 19 September 2008
}

\begin{abstract}
The use of a commercially available thiazolium salt facilitated an intramolecular Stetter reaction between an aliphatic aldehyde and an acrylate unit, which delivered a trans,syn-fused bicyclic pyranone in high yield as a single diastereomer. The pyranone was used to synthesize a trans,syn,trans-fused polycyclic ether array and was ring expanded to give the corresponding oxepanone.
\end{abstract}

Key words: carbenes, diastereoselectivity, fused-ring systems, ring closure, umpolung

The direct addition of an aldehyde onto a Michael acceptor to give a 1,4-dicarbonyl system was reported in the early 1970's by Stetter and co-workers. ${ }^{1}$ The reversal in conventional reactivity of the aldehyde unit (umpolung ${ }^{2}$ ) was brought about by the action of catalytic cyanide. However, that initial protocol was only useful for aromatic aldehydes. In order to affect such a coupling between aliphatic aldehydes and Michael acceptors, Stetter mimicked the thiazolium unit found in co-enzyme $\mathrm{B}_{1}$. Deprotonation of simple, commercially available thiazolium salts generated carbenes, which underwent addition to aldehydes. Proton transfer then generated acyl anion equivalents (Breslow intermediates ${ }^{3}$ ), which underwent addition to unsaturated ketones, esters, and nitriles to deliver 1,4-oxoketones, ketoesters, and ketonitriles, respectively. The potential power of this new catalytic methodology for the intramolecular generation of ring systems lay dormant for many years. Until the work of Ciganek in $1995^{4}$ - more than twenty years after the initial report - only a single example of an intramolecular Stetter reaction had been disclosed. ${ }^{5}$

Interest in the catalytic intramolecular Stetter reaction has been rekindled by attempts to render the procedure enantioselective. Enders pioneered this new push, generating chiral thiazolium salts for use in intra- and intermolecular Stetter reactions. ${ }^{6}$ And the mantle has since been taken up by Rovis, ${ }^{7,8}$ Johnson, ${ }^{9}$ Scheidt, ${ }^{10}$ and others ${ }^{11}$ who have developed high-yielding procedures which give highly enantioenriched products.

Despite the potential of this methodology to give rapid access to ring systems, it possesses some limitations. For in-

SYNLETT 2009, No. 2, pp 0233-0236

Advanced online publication: 15.01.2009

DOI: 10.1055/s-0028-1087519; Art ID: D33108ST

(c) Georg Thieme Verlag Stuttgart · New York

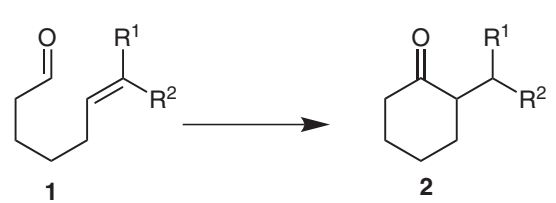

Scheme 1 Intramolecular Stetter reaction of aliphatic substrates

Table 1 Intramolecular Stetter Reaction of Aliphatic Substrates

\begin{tabular}{lll}
\hline $\mathrm{R}^{1}$ & $\mathrm{R}^{2}$ & Yield $(\%)^{\mathrm{a}}$ \\
\hline $\mathrm{COPh}$ & $\mathrm{H}$ & 60 \\
$\mathrm{CO}_{2} \mathrm{Et}$ & $\mathrm{H}$ & 0 \\
$\mathrm{CO}_{2} \mathrm{Et}$ & $\mathrm{CO}_{2} \mathrm{Et}$ & 97 \\
\hline
\end{tabular}

${ }^{a}$ Yields as quoted by Rovis et al. ${ }^{7}$

stance, while the formation of six-membered rings from aliphatic aldehydes and unsaturated ketones is known, ${ }^{12}$ the corresponding reaction involving unsaturated esters has proved elusive. Rovis demonstrated that only highly activated malonate-derived diesters participated in this ring closure (Scheme 1 , Table 1$){ }^{7}$ and that the readily accessible and synthetically valuable ethyl acrylate unit was not electrophilic enough to undergo the intramolecular Stetter reaction.

We became interested in utilizing the intramolecular Stetter reaction for the (re)iterative generation of trans,syn,trans-fused pyran architectures of the type commonly found in polycyclic ethers of marine origin. ${ }^{13}$ It was our intention to use the economical ethyl acrylate unit as the Michael acceptor. This ambitious plan not only utilized an unreactive $\alpha, \beta$-unsaturated ester but one that suffered the additional deactivating effect of possessing a $\beta$-oxygen substituent.

At the outset of this work we were intrigued by a number of questions: i) could we overcome the barrier to intramolecular Stetter reactions between such unactivated esters and aliphatic aldehydes by the presence of an existing ring; ii) would the newly formed ring be stable given that it would possess a $\beta$-alkoxy ester; and iii) would achiral catalysts provide useful levels of diastereomeric (i.e., substrate) control?

We set about answering these questions using a cyclohexane-based system as a model for naturally occurring 

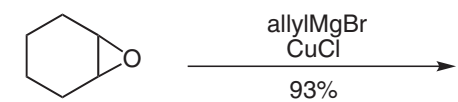

3

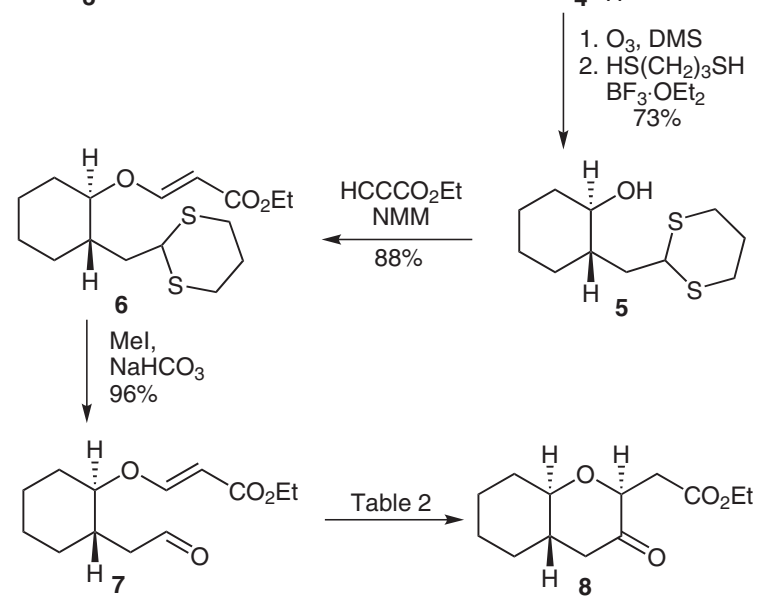

Scheme 2 Synthesis of pyranone 8

pyran arrays (Scheme 2). As such, cyclohexene oxide $\mathbf{3}$ was reacted with allylmagnesium bromide to deliver the known secondary alcohol $\mathbf{4}^{14}$ in good yield. Ozonolytic cleavage of the alkene and treatment with propanedithiol in the presence of boron trifluoride diethyl etherate delivered the dithiane 5. Michael addition of the alcohol to ethyl propiolate in the presence of $N$-methylmorpholine gave the expected $E$-configured alkene $6 .{ }^{15}$ The aldehyde unit was then unmasked to reveal the precursor 7 of the anticipated intramolecular Stetter reaction. Initially, the triazolium salts $\mathbf{9}$ and $\mathbf{1 0}$ described by Rovis were evaluated as potential catalysts for effecting the desired ring closure (Table 2). ${ }^{8}$ Disappointingly, the optimized conditions of Rovis using either $\mathbf{9}$ or $\mathbf{1 0}$ in toluene with KHMDS as a base failed to deliver the desired pyranone 8. After surveying several base and solvent combinations, the desired pyranone was eventually isolated in low yield, but ominously, the bulk of the material had decomposed under the basic reaction conditions.

Switching from a triazolium to a thiazolium-based carbene reagent gave immediate improvement (Table 2, entry 8). Using a mixed solvent system to ensure dissolution of the thiazolium salt $\mathbf{1 1}$ and triethylamine as the base, the desired pyranone $\mathbf{8}$ was isolated in a $29 \%$ yield along with starting material in which the unsaturated ester was present as a mixture of geometric isomers. This suggested that triethylamine was interfering with the acrylate unit and that use of a non-nucleophilic base would be advantageous. With DBU as the base and THF as the solvent (entry 11), the desired pyranone $\mathbf{8}$ was isolated as the sole product in $54 \%$ yield. To the best of our knowledge, this is the first example of an intramolecular Stetter reaction between an aliphatic aldehyde and an unactivated ester to deliver a six-membered ring.

Gratifyingly, $\mathbf{8}$ existed as a single diastereomer. The syn relationship of the protons adjacent to the $\mathrm{O}$ atom of the
Table 2 Conditions for the Intramolecular Stetter Reaction

\begin{tabular}{|c|c|c|c|c|c|}
\hline 9 & & 10 & 11 & & \\
\hline Entry & Salt (mol\% & Solvent & Base & $\begin{array}{l}\text { Temp } \\
\left({ }^{\circ} \mathrm{C}\right)\end{array}$ & $\begin{array}{l}\text { Yield of } 8 \\
(\%)^{\mathrm{b}}\end{array}$ \\
\hline 1 & $9^{a}(30)$ & toluene & KHMDS & r.t. & 0 \\
\hline 2 & $9(30)$ & toluene & $\mathrm{Et}_{3} \mathrm{~N}$ & 60 & 0 \\
\hline 3 & $9(30)$ & $\mathrm{EtOH}$ & $\mathrm{Et}_{3} \mathrm{~N}$ & 60 & 0 \\
\hline 4 & $9(30)$ & $\mathrm{CH}_{2} \mathrm{Cl}_{2}$ & $\mathrm{Et}_{3} \mathrm{~N}$ & r.t. & 0 \\
\hline 5 & $9(30)$ & $\mathrm{CH}_{2} \mathrm{Cl}_{2}$ & $\mathrm{Et}_{3} \mathrm{~N}$ & 40 & 23 \\
\hline 6 & $\mathbf{1 0}^{\mathrm{a}}(100)$ & toluene & KHMDS & r.t. & 0 \\
\hline 7 & $10(30)$ & $\mathrm{CH}_{2} \mathrm{Cl}_{2}$ & $\mathrm{Et}_{3} \mathrm{~N}$ & 40 & 0 \\
\hline 8 & $11(30)$ & toluene-EtOH & $\mathrm{Et}_{3} \mathrm{~N}$ & 70 & 29 \\
\hline 9 & $11(100)$ & toluene & DBU & 110 & trace \\
\hline 10 & $11(100)$ & $\mathrm{EtOH}$ & DBU & 70 & 0 \\
\hline 11 & $11(100)$ & THF & $\mathrm{DBU}$ & 67 & 54 \\
\hline 12 & $11(100)$ & THF & DBU & r.t. & $29^{c}$ \\
\hline 13 & $11(30)$ & THF & DBU & 67 & 44 \\
\hline 14 & $11(150)$ & THF & DBU & 67 & 98 \\
\hline
\end{tabular}

${ }^{\mathrm{a}}$ For synthesis, see ref. ${ }^{8}$.

${ }^{\mathrm{b}}$ Yield of isolated compound after chromatography.

${ }^{\mathrm{c}}$ Reaction was halted after $48 \mathrm{~h}$.

newly formed pyranone was assigned on the basis of NOE experiments (see Supporting Information). The stereochemical outcome of the reaction can be rationalized by noting that the syn-pyranone is more thermodynamically stable than the corresponding trans-isomer. ${ }^{16}$ Given the basic nature of the carbene reagent and the presence of DBU in the reaction mixture, the initial reaction products may be converted into the more stable product by epimerization or by an elimination-addition sequence. Alternatively, we cannot rule out the possibility that the product is the kinetic outcome of Stetter addition to the $E$-alkene.

We next sought to improve the yield of the process (Table 2). Lowering the reaction temperature resulted in an unacceptable decrease in the rate of reaction, which was incomplete after 2 days. As entry 13 shows, the reaction proceeded with a substoichiometric amount of the thiazolium salt, but in reduced yield. Given the commercial availability and low cost of the reagent we did not consider this a serious limitation. Indeed, increasing the amount of thiazolium salt to 1.5 equivalents gave the desired pyranone 8 in $98 \%$ yield. ${ }^{17}$

As expected, hydride reduction of the ketone $\mathbf{8}$ at low temperature was stereoselective, delivering alcohol 12 (Scheme 3). ${ }^{18}$ X-ray crystallographic analysis of the cor- 

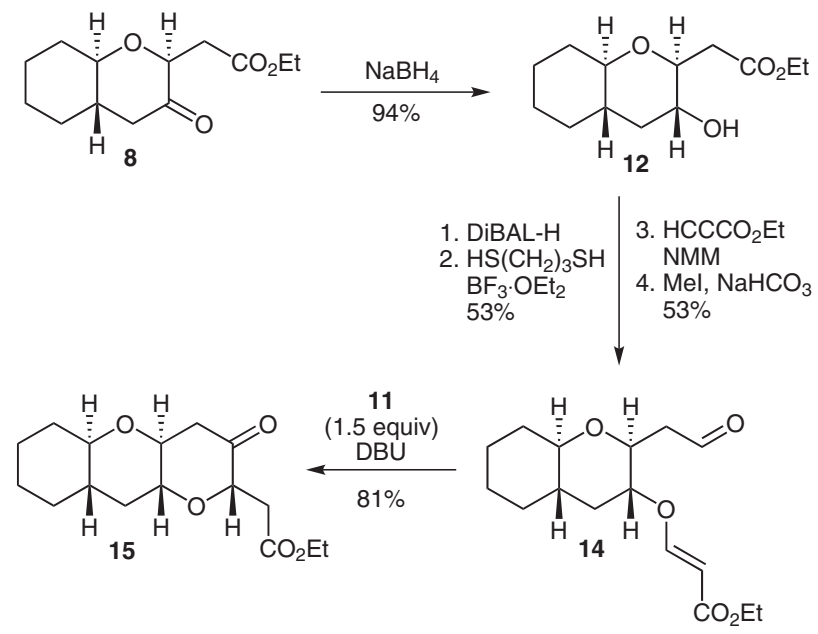

Scheme 3 Iterative synthesis of a polycyclic ether array

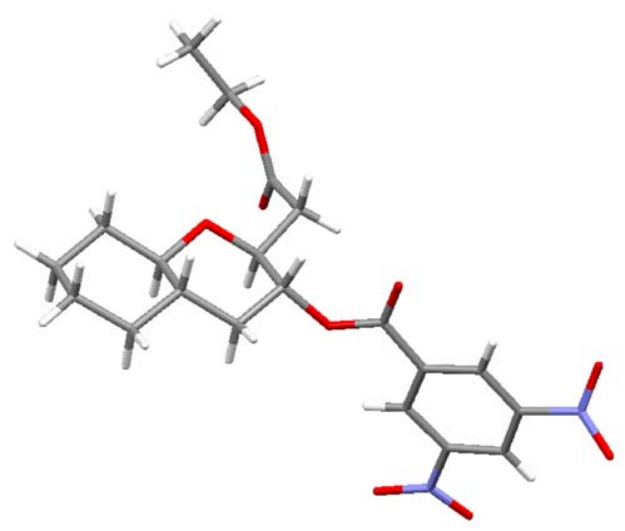

Figure 1 X-ray crystal structure of compound $\mathbf{1 3}$

responding 3,5-dinitrobenzoate 13 established unambiguously the trans,syn,trans stereochemistry of the bicyclic pyran (Figure 1). ${ }^{19,20}$

The alcohol 12 was then carried through another iteration of the ring-forming sequence to deliver the tricyclic compound $\mathbf{1 5}$, which could serve as the substrate for further iterations.

Having demonstrated that the intramolecular Stetter reaction provided access to a stable pyranone product and that the reaction displayed a high level of diastereocontrol, we turned our attention to the question of ring size (Scheme 4). Disappointingly, the corresponding oxepanone 17 was not produced by subjecting the homologous aldehyde $\mathbf{1 6}$ to the conditions used previously. However, pyranone $\mathbf{8}$ could be ring expanded in the known fashion by the action of trimethylsilyldiazomethane to deliver the seven-membered ring. ${ }^{21}$

In summary, we report the first example of an intramolecular Stetter reaction between an aliphatic aldehyde and an acrylate unit to access a trans,syn-fused pyranone as a single diastereomer. This compound was progressed to a

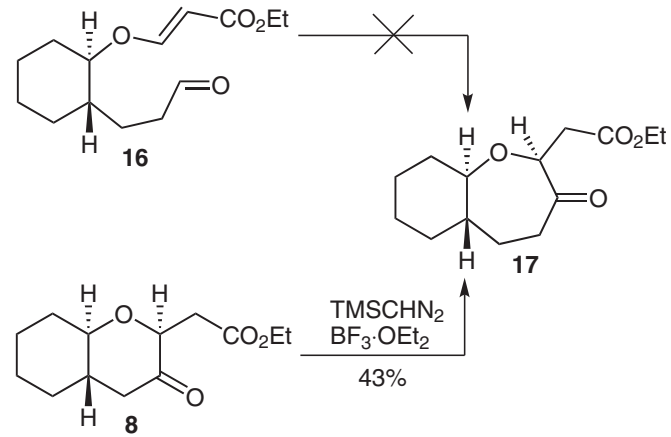

Scheme 4 Oxepanone synthesis

trans,syn,trans-fused polyether array and ring expanded to the corresponding oxepanone. Further studies on substrate-controlled, intramolecular Stetter reactions and their application to the synthesis of natural products will be reported in due course.

Supporting Information for this article is available online at http://www.thieme-connect.com/ejournals/toc/synlett.

\section{References and Notes}

(1) (a) Stetter, H.; Kuhlmann, H. Angew. Chem., Int. Ed. Engl. 1974, 13, 539. (b) Stetter, H. Angew. Chem., Int. Ed. Engl. 1976, 15, 639. (c) Stetter, H. Org. React. 1991, 40, 407.

(2) Seebach, D. Angew. Chem., Int. Ed. Engl. 1979, 18, 239.

(3) Breslow, R. J. Am. Chem. Soc. 1958, 80, 3719.

(4) Ciganek, E. Synthesis 1995, 1311.

(5) Trost, B. M.; Shuey, C. D.; DiNinno, F. Jr.; McElain, S. S. J. Am. Chem. Soc. 1979, 101, 1284.

(6) (a) Enders, D.; Breuer, K.; Runsink, J.; Teles, J. H. Helv. Chim. Acta 1996, 79, 1899. (b) Enders, D.; Balensiefer, T. Acc. Chem. Res. 2004, 37, 534.

(7) Rovis, T.; Kerr, M. S. Synlett 2003, 1934.

(8) (a) Read de Alaniz, J.; Kerr, M. S.; Moore, J. L.; Rovis, T. J. Org. Chem. 2008, 73, 2033. (b) Kerr, M. S.; Read de Alaniz, J.; Rovis, T. J. Am. Chem. Soc. 2002, 124, 10298. (c) Kerr, M. S.; Rovis, T. J. Am. Chem. Soc. 2004, 126, 8876. (d) Rovis, T.; Read de Alaniz, J. J. Am. Chem. Soc. 2005, 127, 6284. (e) Rovis, T.; Moore, J. L.; Kerr, M. S. Tetrahedron 2006, 62, 11477. (f) Kerr, M. S.; Read de Alaniz, J.; Rovis, T. J. Org. Chem. 2005, 70, 5725.

(9) (a) Johnson, J. S. Angew. Chem. Int. Ed. 2004, 43, 1326. (b) Johnson, J. S. Curr. Opin. Drug Discovery Dev. 2007, 10, 691 .

(10) (a) Mattson, A. E.; Bharadwaj, A. R.; Scheidt, K. A. J. Am. Chem. Soc. 2004, 126, 2314. (b) Mattson, A. E.; Bharawaj, A. R.; Zuhl, A. M.; Scheidt, K. A. J. Org. Chem. 2006, 71, 5715.

(11) Enders, D.; Niemeier, O.; Henseler, A. Chem. Rev. 2007, $107,5606$.

(12) (a) Nicolaou, K. C.; Tang, Y.; Wang, J. Chem. Commun. 2007, 1922. (b) Nicolaou, K. C.; Pappo, D.; Tsang, K. Y.; Gibe, R.; Chen, D. Y.-K. Angew. Chem. Int. Ed. 2008, 47, 944.

(13) For polycyclic ethers, see: (a) Bowden, B. Toxin Rev. 2006, 25, 137. (b) Inoue, M. Chem. Rev. 2005, 105, 4379. (c) Lin, Y.-Y.; Risk, M.; Ray, S. M.; Van Engen, D.; Clardy, J.; 
Golik, J.; James, J. C.; Nakanishi, K. J. Am. Chem. Soc. 1981, 103, 6773. (d) Matsuo, G.; Kawamura, K.; Hori, N.; Matsukura, H.; Nakata, T. J. Am. Chem. Soc. 2004, 126, 14374. (e) Nakata, T. Chem. Rev. 2005, 105, 4314. (f) For iterative approaches to polycyclic ethers, see: Sasaki, M. Top. Heterocycl. Chem. 2006, 5, 149. (g) Canoa, P.; Pérez, M.; Covelo, B.; Gómeza, G.; Fall, Y. Tetrahedron Lett. 2007, 48, 3441. (h) Kimura, T.; Nakata, T. Tetrahedron Lett. 2007, 48, 43. (i) Kimber, M. C.; Robertson, J.; McErlean, C. S. P.; Wilson, C.; Clark, J. S. Angew. Chem. Int. Ed. 2005, 44, 6157. (j) Kadota, I.; Yamamoto, Y. Acc. Chem. Res. 2005, 38, 423; and references therein. (k) Trost, B. M.; Rhee, Y. H. Org. Lett. 2004, 6, 4311. (1) For approaches utilizing acrylate esters, see: Marmsater, F. P.; West, F. G. Chem. Eur. J. 2002, 8, 4346; and references therein. (m) Evans, P. A.; Roseman, J. D.; Garber, L. T. J. Org. Chem. 1996, 61, 4880. (n) Hori, N.; Matsukura, H.; Matsuo, G.; Nakata, T. Tetrahedron Lett. 1999, 40, 2811. (o) Hori, N.; Matsukura, H.; Matsuo, G.; Nakata, T. Tetrahedron 2002, 58, 1853.

(14) Hegedus, L. S.; McKearin, J. M. J. Am. Chem. Soc. 1982, 104, 2444.

(15) (a) Winterfeldt, E. Chem. Ber. 1964, 97, 1952. (b) Hori, N.; Matsukura, H.; Matsuo, G.; Nakata, T. Tetrahedron Lett. 1999, 40, 2811.

(16) Betancort, J. M.; Martín, V. S.; Padrón, J. M.; Palazón, J. M.; Ramírez, M. A.; Soler, M. A. J. Org. Chem. 1997, 62, 4570.

(17) Synthesis of Compound 8 To a solution of aldehyde 7 (58 mg, $0.24 \mathrm{mmol}$ ) in THF (2 $\mathrm{mL}$ ) was added thiazolium salt $\mathbf{1 1}(90 \mathrm{mg}, 0.36 \mathrm{mmol})$ and DBU $(54 \mu \mathrm{L}, 0.36 \mathrm{mmol})$. The mixture was stirred under reflux for $16 \mathrm{~h}$, poured onto $\mathrm{H}_{2} \mathrm{O}(30 \mathrm{~mL})$, and extracted with EtOAc $(4 \times 10 \mathrm{~mL})$. The combined organic phases were dried over $\mathrm{Na}_{2} \mathrm{SO}_{4}$, the solvent was evaporated, and the residue was subjected to flash chromatography, eluting with $10 \%$ EtOAc in hexanes, to give $\mathbf{8}(57 \mathrm{mg}, 98 \%)$ as a clear oil. IR $\left(\mathrm{CHCl}_{3}\right): v_{\max }=3093,2977,2931,1735,1720,1450$, $1396,1288,1172,1103,1026 \mathrm{~cm}^{-1}$. ${ }^{1} \mathrm{H}$ NMR $(300 \mathrm{MHz}$, $\left.\mathrm{CDCl}_{3}\right): \delta=4.29(1 \mathrm{H}, \mathrm{dd}, J=6.0,5.7 \mathrm{~Hz}), 4.14(2 \mathrm{H}, \mathrm{q}, J=$ $7.2 \mathrm{~Hz}), 3.36(1 \mathrm{H}$, ddd, $J=9.9,9.9,4.5 \mathrm{~Hz}), 2.87(1 \mathrm{H}, \mathrm{dd}$, $J=16.5,5.4 \mathrm{~Hz}), 2.62(1 \mathrm{H}, \mathrm{dd}, J=16.5,6.3 \mathrm{~Hz}), 2.55(1 \mathrm{H}$, $\mathrm{dd}, J=15.5,4.5 \mathrm{~Hz}), 2.15(1 \mathrm{H}, \mathrm{dd}, J=15.5,12.3 \mathrm{~Hz}), 2.05$ $1.99(1 \mathrm{H}, \mathrm{m}), 1.85-1.62(4 \mathrm{H}, \mathrm{m}), 1.37-1.06(4 \mathrm{H}, \mathrm{m}), 1.25$ $(3 \mathrm{H}, \mathrm{t}, J=7.2 \mathrm{~Hz}) \cdot{ }^{13} \mathrm{C} \mathrm{NMR}\left(75.4 \mathrm{MHz}, \mathrm{CDCl}_{3}\right): \delta=206.6$ (C), $171.0(\mathrm{C}), 80.5(\mathrm{CH}), 79.7(\mathrm{CH}), 60.7\left(\mathrm{CH}_{2}\right), 45.1$ $\left(\mathrm{CH}_{2}\right), 42.9(\mathrm{CH}), 35.3\left(\mathrm{CH}_{2}\right), 32.0\left(\mathrm{CH}_{2}\right), 31.7\left(\mathrm{CH}_{2}\right), 24.9$ $\left(\mathrm{CH}_{2}\right), 24.6\left(\mathrm{CH}_{2}\right), 14.2\left(\mathrm{CH}_{3}\right)$. HRMS: $\mathrm{m} / 2$ calcd for $\mathrm{C}_{13} \mathrm{H}_{21} \mathrm{O}_{4}\left[\mathrm{M}+\mathrm{H}^{+}\right]: 241.14344$; found: 241.14383.

(18) Mori, Y.; Yaegashi, K.; Furukawa, H. J. Am. Chem. Soc. 1996, $118,8158$.

(19) (a) For the synthesis of compound $\mathbf{1 3}$ see Supporting Information. (b) CCDC 702838 contains the supplementary crystallographic data for this paper. These data can be obtained free of charge from The Cambridge Crystallographic Data Centre via www.ccdc.cam.ac.uk/ data_request/cif.

(20) (a) A crystalline $p$-bromobenzoate derivative of a similar fused bicyclic system has been reported. ${ }^{20 \mathrm{~b}}$ Therefore, alcohol 12 was converted into the corresponding $p$-bromobenzoate but that compound failed to provide crystals suitable for X-ray crystallographic analysis. (b) Nicolaou, K. C.; Prasad, C. V. C.; Somers, P. K.; Hwang, C.-K. J. Am. Chem. Soc. 1989, 111, 5330.

(21) (a) Shioiri, T.; Hashimoto, N.; Aoyama, T. Tetrahedron Lett. 1980, 21, 4619. (b) Mori, Y.; Yaegashi, K.; Furukawa, H. J. Am. Chem. Soc. 1997, 119, 4557. (c) Mori, Y.; Nogami, K.; Hayashi, H.; Noyori, R. J. Org. Chem. 2003, 68, 9050. 